\title{
The Relationship of Frequency and Intensity of Bleeding with Hemophilic Arthropathy in Hemophilia Patients, Radiological Assesment and Socio-Economic Impacts of the Arthropathy
}

\author{
Orhan ZENGIN ${ }^{1}$, Vahap OKAN $^{2}$, Ayhan OZKUR ${ }^{3}$, Zeynel A. SAYINER ${ }^{1}$ \\ Handan H. SAHIN ${ }^{2}$, Mehmet YILMAZ ${ }^{2}$, Mustafa PEHLIVAN ${ }^{2}$ \\ ${ }^{1}$ Gaziantep University, Faculty of Medicine, Department of Internal Medicine, Gaziantep \\ ${ }^{2}$ Gaziantep University Faculty of Medicine, Department of of Hematology,Gaziantep \\ ${ }^{3}$ Gaziantep University Faculty of Medicine, Department of Radiology,Gaziantep, TURKEY
}

\begin{abstract}
Hemophilic arthropathy is the most common complication of hemophilia, and the most important element for follow-up and treatment of hemophilia. In this study, hemophilic arthropathy was evaluated for bleeding, radiological assessment, and physical examination. Besides, socio-economic outcomes of hemophilic arthropathy and its impacts on quality of life were also investigated. Forty male patients diagnosed with hemophilia in the Hematology Unit of Gaziantep University Medical Faculty were included in the study. Of the 40 patients, 34 had hemophilia A and 6 had hemophilia B; 20 (50\%) had severe, 8 (20\%) had moderate and 12(30\%) had mild hemophilia. According to our data collected in this study, there was a close relationship between hemophilic arthropathy and factor level. It was detected that the factor level and frequency of bleeding ( $p<0.05)$, functional assessment of joints $(p<0.05)$ and scores of radiological assessment $(p<0.05)$ was negatively correlated. Frequency of joint bleeding during one-year period had a significantly positive correlation with functional assessment of joints $(p<0.01)$ and scores of radiological assessment $(p<0.01)$. It was observed that quality of life impaired in advanced arthropathy patients whose physical examination and radiological assessment scores were high among those who had more frequent bleedings. In addition, with increased frequency of bleeding, factor consumption and treatment costs are also increasing. Hemophilic arthropathy is a serious disease that imposes a large economic burden on patients and society. The full treatment of the disease may only be possible if the treatment is started at an early age and during this period it is crucially important to prevent joint bleedings, rehabilitate disabilities, and to introduce patients into society.
\end{abstract}

Keywords: Hemophilia, Hemophilic arthropathy, Bleeding, Quality of life

\section{ÖZET}

Hemofilik Hastalarda Hemofilik Artropatinin Kanama Sıklığı ve Şiddeti İle ilisşkisi, Artropatinin Radyolojik Değerlendirmesi ve Sosyoekonomik Sonuçları

Hemofilinin en sık komplikasyonu hemofilik artropatidir. Bu nedenle hemofili takip ve tedavisindeki en önemli unsurdur. Bu çalışmada hemofilik artropati kanama, radyolojik değerlendirme ve fizik muayene yönünden değerlendirildi. Ayrıca hemofilik artropatinin sosyoekonomik sonuçları ve yaşam kalitesi üzerine etkileri araştırıdı. Çalışmaya Gaziantep Üniversitesi Tıp Fakültesi Hematoloji Bilim Dalı'nda hemofili tanısıyla takip edilen 40 erkek hasta dahil edildi. Hastalardan 34'ü hemofili A, 6'sı hemofili B idi. Faktör düzeylerine göre ise 20 hasta (\%50) ağır hemofili, 8 hasta (\%20) orta hemofili, 12 hasta (\%30) hafif hemofili idi. Çalışmamızda elde edilen sonuçlara göre hemofilik artropati oluşumunun faktör düzeyiyle yakından ilişkili olduğu görülmüştür. 
Faktör düzeyi ile kanama sayısı ( $p<0.05)$, eklemin fonksiyonel değerlendirme $(p<0.05)$ ve radyolojik değerlendirme skorları $(p<0.05)$ arasında negatif korelasyon olduğu görülmüştür. Hastaların bir yllık dönemdeki eklem kanama sayısı eklemin fonksiyonel değerlendirmesi $(p<0.01)$ ve radyolojik değerlendirme $(p<0.01)$ arasında anlamlı pozitif ilișki olduğu görüldü. Kanama sayısının arttığı, fizik muayene ve radyolojik değerlendirme skorları yüksek olan ilerlemiş artropatisi olan hastaların yaşam kalitelerinde azalma görülmüştür. Ayrıca kanama sayısı artması ile faktör tüketimi ve tedavi masrafları artmaktadır. Hemofilik artropati kişiye ve topluma gerek sosyal gerek ekonomik açıdan önemli oranda yük bindiren ciddi bir sağılı sorunudur. Tam anlamılla tedavisi erken yaşlarda başlamak üzere eklem kanamalarının önlenmesi, var olan sakatlıkların düzeltilmesi ve hastaların topluma kazandırımaları ile mümkün olabilir.

Anahtar Kelimeler: Artropati, Kanama, Yaşam kalitesi

\section{INTRODUCTION}

Hemophilia is a hereditary disease caused by deficiency of coagulation factor VIII (FVIII) or factor XI (FXI). With bleeding as one of its common complications, it is observed to have three different clinical courses as severe, moderate or mild based on the frequency and extent of bleeding. Its prevalence in general population is reported to be $12.8 \pm 6 / 100,000 .^{1-3}$ The most significant and common complication in severe and moderate hemophilia cases is bleedings of the musculoskeletal system. Over time, these bleedings, that emerge in the form of hemarthrosis most of the time, lead to development of hemophilic arthropathy by causing intra-articular degenerative changes. ${ }^{4}$

Hemophiliacs form a significant subgroup of the disabled young population in developing countries. The absolute necessity of expensive blood products in its treatment highly increases the treatment costs. It is not possible to overcome this disease, which causes life-threatening bleedings and high disability rates within the young population, unless it is addressed as a public health issue. Hemophilia should be considered a crucial health issue as a disease that imposes a significant amount of burden on the patients, patients' families, and the society. ${ }^{2,5}$

Hemophilic arthropathy is currently a crucial topic for it causes many psychosocial and socioeconomic issues such as disability, loss of workforce, high treatment costs, and patients' detachment from the society. ${ }^{6}$ In this context, hemophilic arthropathy affects quality of life. Therefore, monitoring of hemophilic arthropathy following a diagnosis in early stages and administering the appropriate treatment should be targeted. ${ }^{7}$
The aim of this study was to evaluate the hemophilia patients with severe, moderate, and mild bleedings who were followed up at our clinic in terms of joint functions and radiologic imaging; and to investigate arthropathy's association with number of bleedings, amount of factors used, and the factor levels. Additionally, investigation of which factors are more valuable in guiding in terms of diagnosis, follow-up, and treatment of hemophilic arthropathy; and identification of the effect loss of joint functions has on patients' quality of life were also aimed at.

\section{PATIENTS AND METHODS}

A total of 40 male patients, who were followed up at the Hematology Unit of Gaziantep University Medical Faculty throughout 2010 with hemophilia diagnosis were included in the study. Occupation and duration of education of these patients were recorded based on self-reports. They were also asked to report any other comorbid diseases they were diagnosed with for and drugs they had been using in the past two weeks other than factor treatment. The patients' wrist, elbow, shoulder, hip, knee, and ankle joint physical examination findings were scored separately for each joint. Physical examination score was calculated based on the contracture ( 0 points if none, 1 if $<10 \%, 2$ if 10 to $33 \%$, and 3 if $>33 \%$ ), the range of motion loss ( 0 points if none, 1 if $<10 \%, 2$ if 10 to $33 \%$, and 3 if $>33 \%$ ), swelling (1 point), muscle atrophy (1 point), and crepitation (1 point).

All information on joint bleeding, location of bleedings, number of bleedings, and the factor 


\begin{tabular}{|llll|}
\hline \multicolumn{3}{|l|}{ Table 1. Arthropathy evaluation results of hemophilia A and B } & \\
\hline & Hemophilia A & Hemophilia B & p-value \\
\hline Yearly factor consumption (units) & $45823.7 \pm 5191.4$ & $41252.7 \pm 4282.3$ & $\mathrm{p}>0.05$ \\
Quality of life score & $33.4 \pm 2.1$ & $32.6 \pm 6.9$ & $\mathrm{p}>0.05$ \\
Number of bleedings & $7.9 \pm 1.1$ & $6.1 \pm 2.1$ & $\mathrm{p}>0.05$ \\
Physical examination score & $13.2 \pm 2.1$ & $12.0 \pm 3.9$ & $\mathrm{p}>0.05$ \\
Radiologic score & $13.9 \pm 2.5$ & $11.9 \pm 1.5$ & $\mathrm{p}>0.05$ \\
\hline
\end{tabular}

used following bleeding for the one year were recorded for each patient. Monthly factor doses were also recorded for patients receiving prophylaxis. Blood samples were obtained from the patients and factor and inhibitor levels were measured. The patients were classified based on their factor levels as severe if it was $<1 \%$, moderate if $1-5 \%$ and as mild if $>5 \%$.

The body weight of the patients were measured and recorded. Bi-directional radiograph of bilateral wrist, elbow, shoulder, hip, knee, and ankle joints of patients were taken and their radiologic evaluation was made using the Patterson scale. ${ }^{8}$ A radiologic score was obtained for each patient. Arthritis Registry Monitoring Database-Multidimensional Health Assessment

Questionnaire (ARMD-MDHAQ) was administered to each patient for quality of life evaluation. ${ }^{9}$

Approval of the Gaziantep University's Medical Ethics Committee (date: 05.05.2011; decision number: 05/2011-08) was obtained; and informed consent was signed by each patient.

The descriptive statistical analyses of data are reported as mean \pm standard deviation. The level of statistical significance is set as $\mathrm{p}<0.05$. Comparisons of more than two groups were made using non-parametric Kruskall-Wallis and analysis of variance tests. Correlations between different parameters were evaluated with Pearson correlation analysis.

\section{RESULTS}

There were 40 male patients diagnosed with hemophilia included in this study. Of the 40 patients, 34 had hemophilia A and 6 had hemophilia B; $20(50 \%)$ had severe, $8(20 \%)$ had moderate and $12(30 \%)$ had mild hemophilia. The mean age of the patients included in the study was $33.5 \pm 1.7$ years. When evaluated based on their factor levels, $20(50 \%)$ were classified as having severe, $8(20 \%)$ moderate, and 12 (30\%) mild hemophilia.

Results of arthropathy evaluations of hemophilia A and B patients are displayed in Table 1.

Hemophilia A and hemophilia B patients were determined to have mean quality of life scores of $33.4 \pm 2.1$ and $32.6 \pm 6.9$; number of bleedings of $7.9 \pm 1.1$ and $6.1 \pm 2.1$; physical examination scores of 13.2 \pm 2.1 and 12.0 \pm 3.9 ; and radiologic scores of $13.9 \pm 2.5$ and $11.9 \pm 1.5$, respectively, and no statistically significant difference was observed between the groups (Table 1).

There were 10 (25\%) patients who did not have any bleeding within the 1-year follow-up period.

\begin{tabular}{|c|c|c|c|c|}
\hline & \multicolumn{2}{|c|}{ Number of bleedings } & \multicolumn{2}{|c|}{ Factor level } \\
\hline & $r$ & $p$ & $r$ & $\mathrm{p}$ \\
\hline Physical examination score & 0.616 & $<0.001$ & -0.456 & $<0.05$ \\
\hline Radiologic score & 0.486 & $<0.001$ & -0.394 & $<0.05$ \\
\hline Quality of life score & 0.606 & $<0.001$ & -0.124 & $>0.05$ \\
\hline
\end{tabular}


Table 3. Comparison of patients by prophylaxis use

\begin{tabular}{|lllll|}
\hline & $\begin{array}{l}\text { Number of } \\
\text { bleedings }\end{array}$ & $\begin{array}{l}\text { Physical Examina- } \\
\text { tion Score }\end{array}$ & $\begin{array}{l}\text { Quality of Life } \\
\text { Score }\end{array}$ & Radiologic Score \\
\hline Non-prophylactic & $7.3 \pm 1.2$ & $12.1 \pm 2.0$ & $32.2 \pm 2.4$ & $13.2 \pm 2.8$ \\
Prophylactic & $4.0 \pm 2.0$ & $18.0 \pm 1.0$ & $35.5 \pm 4.5$ & $11.0 \pm 2.0$ \\
p-value & $>0.05$ & $>0.05$ & $>0.05$ & $>0.05$ \\
\hline
\end{tabular}

Among the patients who had bleedings, the joint with most frequent bleedings was left knee in 14 (35\%), followed by right knee in $6(15 \%)$ patients. Each of right ankle, left elbow, and right elbow were observed in $2(5 \%)$ patients.

The correlation of arthropathy evaluation scores with number of bleedings and factor levels is presented in Table 2.

Number of bleedings was significantly positively correlated to physical examination, radiologic, and quality of life scores $(\mathrm{p}<0.01)$. While factor level was significantly positively correlated to physical examination and radiologic scores $(\mathrm{p}<0.05)$, it was not correlated to quality of life ( $p>0.05$ ) (Table 2 ). Moreover, a significant positive association was observed between physical examination score and radiologic score $(\mathrm{p}<0.01)$.

There were $23(57.5 \%)$ unemployed patients and $2(5 \%)$ patients were employed in a physically active position. The mean duration of education completed by the patients was determined to be $7.8 \pm$ 0.5 years. In addition, a negative correlation was observed between duration of education and radiologic and physical examination scores $(\mathrm{p}<0.05)$.

While 5 patients $(12.5 \%)$ were on prophylactic treatment, the remaining $35(87.5 \%)$ were not. Comparison of the patients according to prophylaxis is presented in Table 3 .

When evaluated by clinical, radiologic, or socioeconomic characteristics, comparison of the patients by use of prophylaxis yielded no significant difference ( $p>0.05$ for number of bleeding, physical examination score, quality of life score, and radiologic score) (Table 3).

It was determined that both age and gender were not associated with any of the other parameters collected.

\section{DISCUSSION}

Hemophilia, by causing hemarthrosis, leads to functional, psychiatric, social, and economic problems for the patients. These issues often impact social and professional life, education, and family of the patient. Therefore, prevention of hemarthrosis before it develops, evaluation of its extent, and early diagnosis and treatment form the basis of hemophilia treatment. ${ }^{10,11}$

Records of the joint bleedings yielded that the joints with most frequent bleeding were left knee in $14(35 \%)$ and right knee in $6(15 \%)$ patients. The possible reasons for the frequent bleedings observed in the knee joints are their frequent use and the heavy load on them. Elbows and ankles are also among the frequently bleeding joints. No wrist bleeding was observed among the patients. All of these findings are consistent with the medical literature. ${ }^{16}$

When the hemophilia cases were compared based on their factor levels, classified as severe, moderate, and mild, factor levels was observed to be negatively correlated with the number of bleedings, and the physical examination and radiologic scores. These findings are compatible with the results of prior studies demonstrating that factor level is proportionate with the frequency and the intensity of bleeding. ${ }^{17}$

Gilbert's ${ }^{11}$ article evaluating hemarthrosis reported a weak association between clinical and radiologic scores and stated that a treatment based solely on radiologic findings will therefore be inappropriate. Helkske's ${ }^{14}$ study investigating permanent joint damage in hemophilia patients emphasized that the extent of arthropathy was best evaluated with physical examination. Pettersson et al.'s ${ }^{8}$ study on the other hand reported no significant differences in 
radiologic findings despite a decrease in bleeding episodes and improvements in physical examination findings via prophylactic factor replacement, and therefore emphasized that radiologic findings were not always consistent with the physical examination findings. In this study, a significant positive association $(p<0.01)$ was detected between physical examination and radiologic scores. This result may indicate that radiologic evaluations alone may not be sufficient in evaluations before and after prophylaxis administration. However, it may be concluded that in the evaluation of hemophilia's long-term effects, as in our study, both physical examination and radiology can be used safely and that their findings are associated. Therefore, while planning hemarthrosis treatment, it would be beneficial to use physical examination and radiologic evaluations together.

Again, in this study, number of bleedings was significantly positively correlated to physical examination, radiologic, and quality of life scores. According to this finding, while a single bleeding could initiate the hemarthrosis process, repeated bleedings could worsen the physical examination and radiologic findings and impair their quality of life by affecting their functional capacity. As a result, increased bleeding episodes increase factor treatment doses and treatment costs.

In a study by Ramgren, while $13 \%$ of the patients were not employed, of the severe hemophilia cases $75 \%$ had a desk-job and only $0.04 \%$ were determined to have a hard labor occupation. ${ }^{12}$ Among our patients, unemployment rate was $57.5 \%$ (23 patients) and only 2 patients (5\%) were employed in a mobile, hard-labor position. Accordingly, though these ratios are similar to those in Ramgren's study, unemployment rate among hemophilia patients seems to be higher in Turkey's conditions. Undoubtedly, it could also be closely associated with the limited opportunities in Turkey as well.

A study on hemophilia's impact on education by Ramgren reported that $58 \%$ of severe and $78 \%$ of moderate hemophilia patients completed primary education. Another study by Favre-Gilly showed that only $30 \%$ of the patients reached high-school and $10 \%$ reached college level of education. ${ }^{12}$ Compatible with the findings of these studies, the mean duration of schooling completed by the patients in our study was $7.8 \pm 0.5$ years, which is equivalent to secondary education in Turkish educational system. In our study, duration of schooling was observed to be negatively correlated to radiologic and physical education scores $(\mathrm{p}<0.05)$. This indicates that arthropathy impedes the education of patients.

In Rosbach's study, it was concluded that, though more expensive, prophylaxis improves clinical results and quality of life more than treatment as bleeding occurs. ${ }^{20}$ In Fischer et al.' ${ }^{23}$ study, patients who were receiving treatment as they bled had an average of 1494 joint bleedings over a lifetime and had used 4.9 million units of factor on average. On the other hand, those receiving a moderate dose of prophylaxis had an average of 357 joint bleedings over a lifetime and had used 8.3 million units of factor on average. With multiple therapy approach (administering prophylaxis according to bleeding pattern or treatment as necessary), the average lifetime joint bleedings were found to be 395 and the factor units used was 6.6 million. As a result, it was emphasized that various treatment strategies could be used based on joint bleeding and factor use evaluations. In our study, 35 of patients received treatment as bleeding occurred and 5 were on prophylaxis. No statistically significant difference was observed between them in terms of number of bleedings, and physical examination, quality of life and radiologic scores. This lack of difference between patients receiving prophylaxis and those receiving treatment as necessary may be due to the small sample size and that the patients were not followed up for a long period of time. On the other hand, the possible cause of this may be that all of these patients were administered secondary prophylaxis (prophylaxis that is initiated after the bleeding episodes increase).

Prior studies reported an association between severity of hemarthrosis and age. Decline in joint functions was reported to accompany hemarthrosis that is advancing with age. However, in our study, age was not associated with physical examination scores, number of bleedings, and radiologic scores. ${ }^{13,14}$ 
The primary limitation of this study is the small sample size, followed by lack of long-term followup of the patients. Additionally, the low number of patients on prophylaxis compared to the treatmentas-necessary group can be stated as another limitation.

In conclusion, as reported before, treating hemophilia patients as bleeding occurs does not prevent hemophilic arthropathy and the patients' functional condition and quality of life are impaired as arthropathy advances. This also makes it difficult for the patients to get education, find employment, and support themselves. Developed countries have resolved this issue by initiating prophylactic treatment programs and starting special education centers. This has both prevented arthropathy and enabled the patients to complete their education and find employment; therefore rehabilitated hemophilia patients back to the society and prevented work force and economic resource loss. ${ }^{10}$

\section{REFERENCES}

1. Di Michele D, Neufeld EJ. Hemophilia. A new approach to an old disease. Hematol Oncol Clin Nort Am 12: 1315-1344, 1988.

2. Kavakli K. Hemofili Hasta Okulu, Ege Hemofili Dernegi Yayinlari. Izmir, Meta Basimevi, 2003: 1-15.

3. Stonebraker JS, Bolton-Maggs PH, Michael Soucie J, Walker I, Brooker M. A study of variations in the reported haemophilia A prevalence around the world. Haemophilia 16: 20-32, 2010.

4. Rodriguez-Merchan EC. Effects of hemophilia on articulations of children and adults Clin Orthop Rel Res 328: 7-13, 1996.

5. Kavakli K. Hemofili hastalarP, yakPnlarP ve Hekimler için: Hemofili Rehberi. Izmir: Ege Hemofili Dernegi Yayinlari. Meta Basimevi, Izmir, 2001: 5-35.

6. Lusher JM. Considerations for current and future management of hemophilia and its complications. Hemophilia 1: 2-10, 1995

7. Schramm W. Experience with prophylaxis in Germany. Semin Hematol 30: 12-15, 1993.

8. Pettersson H, Ahlberg A, Nilsson IM. A radiologic classification of hemophilic arthropathy. Clin Orthop Relat Res 149: 153-159, 1980.
9. Pincus T, Yazici Y, Castrejón I. Pragmatic and scientific advantages of MDHAQ/ RAPID3 completion by all patients at all visits in routine clinical care. Bull NYU Hosp Jt Dis 70 Suppl 1: 30-36, 2012.

10. Smith PS, Keyes NC, Forman EN. Socioeconomic evaluation of a state-funded comprehensive hemophilia-care program. N Eng J Med 306: 575-579, 1982.

11. Gilbert MS. Prophylaxis: Musculoskeletal evaluation. Semin Hematopol 30: 3-6, 1993.

12. Arnold WD, Hillgartner MW. Hemophilic arthropathy. Current concepts of pathogenesis and management. J Bone Joint Surg Am 59: 287-305, 1977.

13. Thompson A. Molecular biology of Hemophilias. Progress Haemos Thorb 10: 175-214, 1991.

14. Helske T, Ikkala E et al. Joint involvement in patients with severe hemophilia A in 1957-59 and 1978-79. Br J Hematol 52: 643-647, 1982.

15. Ramgren O. Hemophilia in Sweden. Acta Med Scan 171: 4658, 1962.

16. Rossbach Hans-Christoph. Vasc Health Risk Manag 6: 5968, 2010.

17. Fischer K, Pouw ME, Lewandowski D, Janssen MP, van den Berg HM, and Hout BA. A modeling approach to evaluate long-term outcome of prophylactic and on demand treatment strategies for severe hemophilia A. Haematologica 96: 738$743,2011$.

18. Gamble JG, Vallier H, Rossi M, Glader B. Loss elbow and wrist motion in hemophilia. Clin Orthop 328: 94-101, 1996.

\section{Correspondence}

Dr. Zeynel Abidin SAYINER

Gaziantep Üniversitesi Tıp Fakültesi

Iç Hastalıkları Anabilim Dalı

27100 Şahinbey

GAZIANTEP / TURKEY

e-mail: zeynelasayiner@hotmail.com

Tel: (+90.342) 3606060 / 76160

Fax: (+90.342) 3603928 